\title{
The Effect of Inhibitors on the Formation of Flagella by Salmonella typhimurium
}

\author{
By D. KERRIDGE \\ M.R.C. Unit for Chemical Microbiology, Department of Biochemistry, \\ Tennis Court Road, Cambridge
}

(Received 25 May 1960)

\begin{abstract}
SUMMARY
The synthesis of flagella by Salmonella typhimurium was used in a study of factors affecting the formation of a single protein. Regeneration of flagella by mechanically deflagellated organisms was completely inhibited by $2: 4$-dinitrophenol $(0.001 \mathrm{M})$, but not by sodium azide $(0.004 \mathrm{M})$, or by sodium arsenate $(0.002 \mathrm{M})$. Ultraviolet (u.v.) irradiation or treatment with nitrogen mustard in a dose sufficient to result in a $99.99 \%$ decrease in viable count, completely inhibited regeneration of flagella. None of the amino acid, purine or pyrimidine analogues tested, with the exception of $p$-fluorophenylalanine, prevented the regeneration of functional flagella, although many of them inhibited bacterial growth. Flagella synthesized in the presence of $p$-fluorophenylalanine were non-functional and the flagella wavelength was half that of the control. Growth of $S$. typhimurium at $44^{\circ}$ resulted in a progressive decrease in the number of flagella/bacterium. On continued incubation at $44^{\circ}$ the culture became non-motile. Subsequent incubation at $37^{\circ}$ resulted in the recovery of motility after a lag about equal to the mean generation time of the bacteria. Addition of 2-thiouracil or 8-azaguanine to a non-motile culture immediately after transferring from $44^{\circ}$ to $37^{\circ}$ prevented the recovery of motility. When the addition of 8-azaguanine was delayed for $1 \mathrm{hr}$. after transferring from $44^{\circ}$ to $37^{\circ}$, there was no inhibition of recovery of motility. The growth of $S$. typhimurium at $37^{\circ}$ was not completely inhibited by 2 -thiouracil ( $\left.0.001 \mathrm{M}\right)$ or 8 -azaguanine (0.001 $\left.\mathrm{M}\right)$, but there was a fall in no. flagella/bacterium after the addition of the analogue. Since regeneration of flagella occurred at $44^{\circ}$, these data were interpreted as indicating that the systems responsible for the formation of flagella were absent from cultures grown at $44^{\circ}$, but were synthesized during the lag before the appearance of flagella on transferring the culture to $37^{\circ}$.
\end{abstract}

\section{INTRODUCTION}

Mechanical removal of flagella from Salmonella typhimurium results in the bacteria becoming non-motile, but has no effect on their viability (Stocker, 1957; Stocker \& Campbell, 1959); on incubation under suitable conditions these bacteria are able to regenerate flagella and so regain their motility. Since flagella from $S$. typhimurium consist of a single well-characterized protein (Kauffmann, 1954; Ambler \& Rees, 1959), regenerating flagella provide a suitable system for studying protein synthesis (Kerridge, 1959a). Quadling \& Stocker (1956) found that it was 
possible to transfer a logarithmically growing culture of $S$. typhimurium from an environment in which flagellar formation occurred normally, to one in which formation of flagella ceased although growth continued. It is possible, by continued incubation under conditions unfavourable for the synthesis of flagella, to obtain a culture of non-motile organisms. These bacteria do not lose the potentiality for the production of flagella and on transfer to favourable conditions regain their motility after a short lag.

Inhibitors play an important role in any investigation of the mechanisms of protein synthesis by micro-organisms. Certain amino acid analogues are incorporated into bacterial protein, often with the production of biologically inactive protein (Munier \& Cohen, 1956, 1959; Baker, Johnson \& Fox, 1958). Since Matthews (1953) showed that 8-azaguanine is incorporated into the ribonucleic acid (RNA) of tobacco mosaic virus, numerous workers have studied the effect of purine and pyrimidine analogues on nucleic acid and protein synthesis and their interrelationship. In Staphylococcus aureus, the formation of the inducible enzymes $\beta$-galactosidase and catalase was found to be more sensitive to inhibition by 8-azaguanine than the constitutive glucozymase system (Creaser, 1956). Richmond (1959), who studied enzyme formation in Bacillus subtilis $\mathbf{R}$, found that both inducible $\beta$ galactosidase and constitutive lytic enzyme formation were equally sensitive to inhibition by 8-azaguanine.

Cultures of Salmonella typhimurium can be made non-flagellate by either the mechanical removal of their flagella or by growth at $44^{\circ}$, at which temperature flagella are not produced. The first section of this paper describes an investigation of the effects of inhibitors on the regeneration of flagella by mechanically deflagellated bacteria; the second section describes their effects on the recovery of motility at $37^{\circ}$ by $S$. typhimurium grown at $44^{\circ}$. Preliminary reports of this work have been given (Kerridge, 1959).

\section{METHODS}

Organisms and growth media. The strains of Salmonella typhimurium used are detailed in Table 1. The cultures were maintained on Dorset's egg slopes at room temperature.

Table 1. Characteristics of strains of Salmonella typhimurium used

\begin{tabular}{|c|c|c|c|c|}
\hline Strain & $\begin{array}{c}\text { Parent } \\
\text { strain }\end{array}$ & Characteristic & $\begin{array}{l}\text { Lab. ref. } \\
\text { no. }\end{array}$ & Source \\
\hline LT2 & $\bar{T}$ & Wild-type & LT2 & Zinder \& Lederberg (1952) \\
\hline & LT2 & Monophasic H (1.2.3.) & SW 1061 & Dr T. Iino \\
\hline SW 577 & - & $90 \%$ 'curly' flagella & SW 577 & Dr E. Leifson \\
\hline 462 & 553 & Tyrosine requiring & SL 185 & Dr H. Plough \\
\hline $\operatorname{try} A-8$ & LT2 & Tryptophan requiring & SL282 & Demerec et al. (1956) \\
\hline phe-5 & LT2 & Phenylalanine requiring & SL 448 & Demerec et al. (1956) \\
\hline
\end{tabular}

Unless otherwise stated, Salmonella typhimurium strain SW 1061 was used for the experimental work.

For the preparation of washed suspensions, organisms were grown in a nutrient broth made from a pancreatic digest of casein, dispensed in $150 \mathrm{ml}$. quantities in Roux bottles. The inoculum was $3 \mathrm{ml}$. of an overnight culture of the organism in 
nutrient broth. The bacteria were harvested by centrifugation after incubation for $4 \mathrm{hr}$. at $37^{\circ}$. The organisms were washed twice with saline $(0.85 \%, \mathrm{w} / \mathrm{v})$ and resuspended in saline at a concentration equivalent to $10 \mathrm{mg}$. dry wt./ml. The equiv. dry weights of the organisms in suspension were estimated by using a Hilger 'Spekker' absorptiometer previously calibrated for the organisms. The flagella were detached mechanically from the bacteria as previously described (Kerridge, 1959a).

Non-motile cultures of Salmonella typhimurium were obtained by growing the bacteria at $44^{\circ}$ in a medium consisting of $(\%, w / v): \mathrm{K}_{2} \mathrm{HPO}_{4}, \mathbf{0 . 7} ; \mathrm{KH}_{2} \mathrm{PO}_{4}, \mathbf{0 . 2}$; $\mathrm{Na}_{3}$ (citrate) $5 \mathrm{H}_{2} \mathrm{O}, 0.05 ; \mathrm{MgSO}_{4} 7 \mathrm{H}_{2} \mathrm{O}, 0.01 ;\left(\mathrm{NH}_{4}\right)_{2} \mathrm{SO}_{4}, 0.01$; Difco vitamin-free Casamino acids, $\mathbf{0} \cdot \mathbf{2}$; glucose, $\mathbf{0 \cdot 2}$.

Regeneration of bacterial flagella. Regeneration of flagella was carried out in $250 \mathrm{ml}$. conical flasks containing $(\%, \mathrm{w} / \mathrm{v}): \mathrm{K}_{2} \mathrm{HPO}_{4}, 0.7 ; \mathrm{KH}_{2} \mathrm{PO}_{4}, 0.2 ; \mathrm{Na}_{3}$ (citrate) $5 \mathrm{H}_{2} \mathrm{O}, 0.05 ; \mathrm{MgSO}_{4} 7 \mathrm{H}_{2} \mathrm{O}, 0.01$; glucose, $0 \cdot 2$; the following amino acids, each at a concentration of $0.1 \mathrm{mg}$. of the $\mathrm{L}$ isomer $/ \mathrm{ml}$. : glycine, serine, glutamic acid, aspartic acid, valine, leucine, isoleucine, arginine, proline, alanine, histidine, lysine, tyrosine, cysteine, threonine, methionine, ornithine, tryptophan and phenylalanine. When inhibitors other than amino acid analogues were being investigated the amino acid mixture was replaced by Difco vitamin-free Casamino acids $(0.2 \%, \mathrm{w} / \mathrm{v})$. Organisms were added to a final concentration equivalent to $0.2 \mathrm{mg}$. dry wt./ml.; $100 \mathrm{ml}$. medium was incubated at $37^{\circ}$.

Viable counts were performed by the method described by Miles \& Misra (1938) after serial dilution in saline.

Regeneration of flagella was determined both by motility estimations and flagellar staining (Kerridge, 1959a).

Nucleic acid and protein synthesis. The organisms in $10 \mathrm{ml}$. samples were harvested by centrifugation, resuspended in $2.0 \mathrm{ml} .5 \%(\mathrm{w} / \mathrm{v})$ trichloroacetic acid (TCA) and held at $4^{\circ}$ for $2 \mathrm{hr}$. The precipitate was harvested by centrifugation and washed twice with cold $0 \cdot 2 \mathrm{~N}$-perchloric acid. Nucleic acid was extracted from the precipitate with $0.5 \mathrm{~N}$-perchloric acid; two $20 \mathrm{~min}$. extractions at $70^{\circ}$ were sufficient to remove all the nucleic acid. The supernatant fluids from the extractions were combined and made up to $5.0 \mathrm{ml}$. with $0.5 \mathrm{~N}$-perchloric acid. Total nucleic acid was determined after suitable dilution, by measuring the extinction at $260 \mathrm{~m} \mu$ with a Beckman model DUspectrophotometer, and the deoxyribonucleic acid(DNA) by the diphenylamine method of Burton (1956). The residue after the extraction of nucleic acid was taken up in $5.0 \mathrm{ml}$. $\mathrm{N}-\mathrm{NaOH}$ and the protein content estimated colorimetrically with Folin's reagent, by the method of Lowry, Rosebrough, Farr \& Randall (1951).

Incorporation of ${ }^{14} \mathrm{C}$-labelled amino acids. In certain experiments the incorporation of a ${ }^{14} \mathrm{C}$-labelled amino acid was used as a measure of nucleic acid and protein synthesis. The ${ }^{14} \mathrm{C}$-labelled amino acid was added to the regeneration medium at a final concentration of $0.05 \mu \mathrm{c} . / \mathrm{ml}$. Organisms in $1 \mathrm{ml}$. samples were harvested by centrifugation, resuspended in $1 \mathrm{ml} .5 \%(\mathrm{w} / \mathrm{v})$ TCA and held at $4^{\circ}$ for $2 \mathrm{hr}$. The precipitate was washed twice with cold $5 \%(w / v)$ TCA. The nucleic acid was extracted from the precipitate with TCA, one 30 min. extraction at $100^{\circ}$ with $2.0 \mathrm{ml}$. $5 \%(w / v)$ TCA being sufficient to remove all the nucleic acid. The precipitate was removed by centrifugation and the supernatant fluid extracted three times with an equal volume of ether to remove the TCA. The resulting aqueous solution was evaporated to dryness, the residue taken up in $\mathrm{N}-\mathrm{NH}_{4} \mathrm{OH}$ and transferred to a metal 
planchette, containing a piece of lens tissue and $0.03 \mathrm{ml}$. of $0 \cdot 1 \%(\mathrm{w} / \mathrm{v})$ aqueous cetyl trimethylammonium bromide to facilitate the spreading of the sample. The residue after the extraction of the nucleic acid was taken as the protein fraction; this was suspended in $\mathrm{N}-\mathrm{NH}_{4} \mathrm{OH}$ and transferred to a metal planchette. After drying, the radioactivity of the planchette contents was determined by using a Panax type D657 counter in association with a thin mica end-window GeigerMuller tube. Counting was continued for 20 min., or until 1000 counts had been recorded.

Induction and estimation of nitratase activity in rashed suspensions of Salmonella typhimurium. Induction was carried out anaerobically in Thunberg tubes at $37^{\circ}$ in a system consisting of $0.05 \mathrm{M}$-phosphate buffer ( $\mathrm{pH} \mathrm{7.0);0.01} \mathrm{M}-\mathrm{KNO}_{3}$; amino acid mixture as for the regeneration of flagella; $2 \cdot 0 \%(\mathrm{w} / \mathrm{v})$ glucose; organisms to a final concentration equiv. 0.4 mg. dry wt. $/ \mathrm{ml}$. After incubation for $2 \mathrm{hr}$. the organisms were harvested by centrifugation, washed once with distilled water, suspended in distilled water and the concentration determined turbidimetrically. The nitratase activity was determined by the method of Pollock (1946).

Preparation of bacterial flagella. The bacteria were harvested by centrifugation, resuspended in distilled water at a concentration equiv. $100 \mathrm{mg}$. dry wt./ml. and the flagella detached mechanically (Kerridge, 1959 $a$ ). Bacteria were removed by centrifugation for $15 \mathrm{~min}$. at $10,000 \mathrm{~g}$. The supernatant fluid was dialysed overnight at $4^{\circ}$ against distilled water, and the flagella harvested by centrifugation for $40 \mathrm{~min}$. at $105,000 \mathrm{~g}$ in a Spinco Model $\mathrm{L}$ centrifuge. The pellet was taken up in distilled water and after removal of contaminating material by centrifuging at $30,000 \mathrm{~g}$ for $\mathbf{1} \mathrm{min}$., the flagella were harvested by centrifugation at $105,000 \mathrm{~g}$ for $40 \mathrm{~min}$.

Amino acid analysis. The flagellin was hydrolysed in $6 \mathrm{~N}-\mathrm{HCl}$ in sealed tubes for $16 \mathrm{hr}$. at $105^{\circ}$. After removal of $\mathrm{HCl}$ by distillation under reduced pressure the hydrolysate was chromatographed, using the two-solvent system of Boissonas (1950). The amino acids were detected by spraying with $0.01 \%(\mathrm{w} / \mathrm{v})$ ninhydrin in acetone and the colour developed by heating at $105^{\circ}$ for $5 \mathrm{~min}$.

\section{RESULTS}

Effect of various inhibitors on protein, DNA and total nucleic acid synthesis and on the regeneration of flagella by mechanically deflagellated bacteria

Miscellaneous inhibitors. In a study of factors affecting the motility of Proteus vulgaris, de Robertis \& Peluffo (1951) found that motility was inhibited by $p$ chloromercuribenzoate $(0.01 \mathrm{M})$, but not by $0.01 \mathrm{M}$-potassium cyanide, sodium azide, sodium fluoride or sodium malonate. In the present work the motility of Salmonella typhimurium in a nutrient broth was unaffected by 2:4-dinitrophenol $(0.002 \mathrm{M})$, but there was a slight decrease in the proportion of motile bacteria when incubated with sodium arsenate $(0.001 \mathrm{M})$. Although these compounds had little effect on motility, they inhibited regeneration of flagella by mechanically deflagellated $S$. typhimurium. Addition of 2:4-dinitrophenol $(0.001 \mathrm{M})$ to the regeneration medium resulted in the complete inhibition of synthesis of nucleic acid, protein and flagella. Lower concentrations of 2:4-dinitrophenol affected synthesis of flagella and total protein synthesis to about the same extent. Regeneration of flagella was less sensitive to inhibition by sodium arsenate than general protein synthesis : $0.001 \mathrm{M}$-sodium arsenate 
completely inhibited net nucleic acid and protein synthesis, but approximately $50 \%$ of the bacteria regenerated flagella. Even in the presence of $0.002 \mathrm{M}$-sodium arsenate some regeneration of flagella occurred. Sodium azide (0.004 M) did not completely inhibit the synthesis of nucleic acid, protein or flagella by $S$. typhimurium (Table 2).

Nitrogen mustard (Harold \& Ziporin, 1958) and ultraviolet radiation (Kelner, 1953) preferentially inhibit DNA synthesis in micro-organisms; at high dosage, inhibition of RNA and protein synthesis also occurs. In the present work treatment of washed suspensions of Salmonellatyphimurium in saline $(0.85 \%, \mathrm{w} / \mathrm{v})$ with nitrogen mustard (di-(2-chloroethyl) methylamine $\mathrm{HCl}$ ) had a marked inhibitory effect on nucleic acid and protein synthesis when the organisms were subsequently incubated in the regeneration medium. Incubation of a washed suspension of

Table 2. The effect of inhibitors on the regeneration of flagella, and on protein and nucleic acid synthesis by Salmonella typhimurium strain $S W 1061$

\begin{tabular}{|c|c|c|c|c|c|c|c|}
\hline \multirow[b]{2}{*}{ Inhibitor } & \multirow[b]{2}{*}{$\begin{array}{c}\text { Concn. } \\
\text { (M) }\end{array}$} & \multicolumn{3}{|c|}{$\begin{array}{l}\text { Bacterial motility after } 2 \mathrm{hr} \text {. } \\
\text { aerobic incubation at } 37^{\circ} \text { in } \\
\text { the complete regeneration medium }\end{array}$} & \multicolumn{3}{|c|}{$\begin{array}{l}\text { Inhibition }(\%) \text { of synthesis } \\
\text { after aerobic incubation } \\
\text { for } 2 \mathrm{hr} \text {. in the complete } \\
\text { regeneration medium }\end{array}$} \\
\hline & & $\begin{array}{l}\text { Motile } \\
\text { bacteria } \\
(\%)\end{array}$ & $\begin{array}{l}\text { Flagellate } \\
\text { bacteria } \\
(\%)\end{array}$ & $\begin{array}{l}\text { Mean no. } \\
\text { flagella/ } \\
\text { flagellate } \\
\text { bacterium }\end{array}$ & $\begin{array}{c}\text { Total } \\
\text { nucleic } \\
\text { acid }\end{array}$ & DNA & Protein \\
\hline 2:4-dinitrophenol & $\begin{array}{l}0 \\
0 \cdot 0005 \\
0 \cdot 001 \\
0 \cdot 002\end{array}$ & $\begin{array}{r}\mathbf{9 0} \\
\mathbf{5 0} \\
\mathbf{1} \\
\mathbf{1}\end{array}$ & $\begin{array}{c}86 \\
35 \\
\cdot \\
.\end{array}$ & $\begin{array}{c}3 \cdot 6 \\
2 \cdot 1 \\
\cdot \\
\cdot\end{array}$ & $\begin{array}{r}80 \\
100 \\
100\end{array}$ & $\begin{array}{r}\dot{70} \\
100 \\
100\end{array}$ & $\begin{array}{r}\dot{84} \\
94 \\
100\end{array}$ \\
\hline $\mathrm{Na}$ arsenate & $\begin{array}{l}0 \\
0.0005 \\
0.001 \\
0.002\end{array}$ & $\begin{array}{l}70 \\
50 \\
50 \\
50\end{array}$ & $\begin{array}{l}70 \\
49 \\
45 \\
44\end{array}$ & $\begin{array}{l}3 \cdot 5 \\
1 \cdot 8 \\
1 \cdot 7 \\
1 \cdot 5\end{array}$ & $\begin{array}{r}\dot{90} \\
97 \\
100\end{array}$ & $\begin{array}{r}\dot{70} \\
100 \\
100\end{array}$ & $\begin{array}{r}\dot{95} \\
100 \\
100\end{array}$ \\
\hline $\mathrm{Na}$ azide & $\begin{array}{l}0 \\
0 \cdot 002 \\
0 \cdot 004\end{array}$ & $\begin{array}{l}80 \\
60 \\
50\end{array}$ & $\dot{.}$ & $\dot{.}$ & $\begin{array}{l}\dot{41} \\
56\end{array}$ & $\begin{array}{l}\dot{43} \\
68\end{array}$ & $\dot{71}$ \\
\hline
\end{tabular}

S. typhimurium (at equiv. $10 \mathrm{mg}$. dry wt. $/ \mathrm{ml}$.) with $500 \mu \mathrm{g}$. nitrogen mustard $/ \mathrm{ml}$. for 10 min. at room temperature resulted in a $99.9 \%$ decrease in the viable count (Table 3). On subsequent incubation in the regeneration medium, DNA synthesis was completely inhibited and RNA and protein synthesis were 67 and $15 \%$ inhibited, respectively. Regeneration of flagella was almost completely inhibited, for only $8 \%$ of the bacteria regenerated flagella during the $2 \mathrm{hr}$. incubation period. Treatment with lower concentrations of nitrogen mustard resulted in less pronounced effects on nucleic acid and protein synthesis. At $100 \mu \mathrm{g}$. nitrogen mustard $/ \mathrm{ml}$. there was no diminution in protein synthesis during the incubation, but synthesis of flagella was appreciably inhibited. Only $40 \%$ of the bacteria regenerated flagella as compared with $83 \%$ in the control without nitrogen mustard (Table 3).

Ultraviolet irradiation with a dose sufficient to give a $99.9 \%$ decrease in the number of viable bacteria completely inhibited the net synthesis of nucleic acid and protein; regeneration of flagella was not completely inhibited and after incubation for $2 \mathrm{hr}$., $\mathbf{5 0} \%$ of the bacteria had regained motility (Table 3 ).

Antibiotics. Since Fitzgerald, Bernheim \& Fitzgerald (1948) reported that the synthesis of the enzyme system involved in the adaptive utilization of benzoic acid 
by Mycobacterium lacticola was inhibited by streptomycin, numerous other antibiotics have been shown to affect nucleic acid and protein metabolism in microorganisms. Chloramphenicol, aureomycin and terramycin, at the minimum growth inhibitory concentration, completely inhibit the formation of protein by washed suspensions of Staphylococcus aureus (Gale \& Paine, 1951; Gale \& Folkes, 1953). Chloramphenicol has a similar effect on protein and nucleic acid synthesis in Escherichia coli (Hahn \& Wisseman, 1951). Penicillin inhibits the formation of bacterial cell wall (Park \& Strominger, 1957), and it has been claimed recently that streptomycin damages the cell membrane in E. coli (Anand \& Davis, 1960).

Table 3. The effect of nitrogen mustard and u.v. irradiation on the regeneration of flagella and on nucleic acid and protein synthesis by Salmonella typhimurium strain $S W 1061$

$\begin{array}{cc} & \\ & \\ \text { Inhibitor } & \text { Concn. } \\ \text { Nitrogen mustard } \dagger & 0 \\ & 100 \\ & 250 \\ & 500 \\ & 1000 \\ & \text { Irradiation } \\ & \text { time } \\ & \text { (min.) }\end{array}$

u.v. radiation $\ddagger$

$\begin{array}{rcrrrrrr}0 & . & 90 & 86 & 2 \cdot 9 & . & . & \text { 52 } \\ 2 & 1 \cdot 0 & 60 & 55 & 2 \cdot 7 & 80 & 80 & 100 \\ 5 & 0 \cdot 1 & 50 & 49 & 2 \cdot 6 & 100 & 100 & 100 \\ 10 & 0 \cdot 01 & 1 & 1 & . & 100 & 100 & 100\end{array}$

Bacterial motility after $2 \mathrm{hr}$. aerobic incubation at $37^{\circ}$ in the complete regeneration medium

$\overbrace{\begin{array}{c}\text { Residual } \\ \text { viable } \\ \text { cells* }\end{array} \text { bacteria bacteria }}^{\text {Flagellate }} \begin{gathered}\begin{array}{c}\text { Mean no. } \\ \text { flagella/ } \\ \text { flagellate }\end{array} \\ \text { flile }\end{gathered}$

$(\%) \quad(\%) \quad(\%)$ bacterium

$7 \quad 90$

$7 \quad 30$

210

$0 \cdot 1 \quad 5$

$0.01 \quad 1$

$\begin{array}{rr}83 & \mathbf{3 \cdot 9} \\ 40 & \mathbf{2 \cdot 7} \\ \mathbf{3 8} & \mathbf{2 \cdot 8} \\ \mathbf{8} & \mathbf{2 \cdot 8} \\ \mathbf{7} & \mathbf{2 \cdot 6}\end{array}$

Inhibition ( $\%$ ) of synthesis after aerobic incubation for $2 \mathrm{hr}$. in the complete regeneration medium

\section{Total}

nucleic

acid DNA Protein

$\begin{array}{rrr}22 & 17 & 0 \\ 44 & 67 & 0 \\ 67 & 100 & 15 \\ 88 & 100 & 16\end{array}$

* The viable count was made at the beginning of the incubation.

+ Washed suspensions of Salmonella typhimurium were incubated at room temperature with nitrogen mustard before transferring to the regeneration medium.

¥ Irradiation with a Thermal syndicate type T/M5/369 mercury vapour lamp having $95 \%$ emission at $2536 \mathrm{~A}$.

If the system involved in the synthesis and functioning of the bacterial flagellum is closely associated with the bacterial membrane or the cell wall, then it is possible that antibiotics which interfere with the formation of these structures might have a secondary effect on flagellar synthesis. Incubation of Salmonella typhimurium strain SW 1061 in the presence of growth-inhibitory concentrations of penicillin resulted in bacterial lysis. When the flagella were removed mechanically before the addition of penicillin, regeneration of flagella occurred before cell lysis. The addition of sucrose $(20 \%, \mathrm{w} / \mathrm{v})$ to the regeneration medium stabilized the spheroplasts produced as a result of incubation in the presence of penicillin, and these were shown to possess flagella, both by staining and serological reactions. It was shown previously (Kerridge, 1959a) that $S$. typhimurium strain SL 282 (tryptophan-requiring) regenerated flagella in the absence of net protein synthesis when incubated in the absence of tryptophan. In the presence of growth-inhibitory concentrations of 
penicillin, flagellar regeneration occurred in S. typhimurium strain SL282 in the absence of tryptophan without the production of spheroplasts.

Flagella could be detached from penicillin-induced spheroplasts of Salmonella typhimurium, but although the spheroplasts were capable of incorporating ${ }^{14} \mathrm{C}$ labelled aspartic acid into the material insoluble in cold $5 \%(w / v)$ TCA when incubated in the regeneration medium supplemented with $20 \%(\mathrm{w} / \mathrm{v})$ sucrose, synthesis of flagella could not be demonstrated under these conditions.

The addition of a growth-inhibitory concentration of streptomycin to a culture of Salmonella typhimurium did not result in the immediate inhibition of motility. At the minimum growth-inhibitory concentration $(10 \mu \mathrm{g} . / \mathrm{ml}$.) streptomycin had little effect on flagellar regeneration, and even at $100 \mu \mathrm{g}$. streptomycin $/ \mathrm{ml}$. the majority of the bacteria regenerated flagella. Both penicillin and streptomycin at the minimum growth-inhibitory concentration had some inhibitory effect on nucleic acid and protein synthesis by $S$. typhimurium (Table 4 ).

Table 4. The effects of antibiotics on the regeneration of flagella, and on nucleic acid and protein synthesis by Salmonella typhimurium strain $S W 1061$

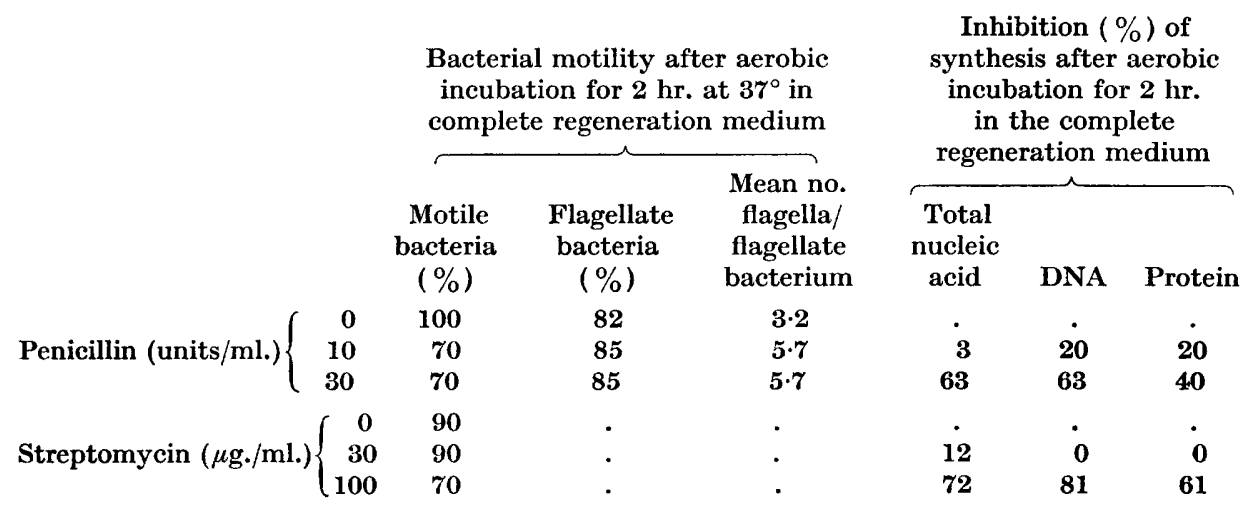

Amino acid analogues. The relative ease of isolation of bacterial flagella makes flagellin synthesis a suitable system for the study of the incorporation of amino acid analogues into a single functional protein; minor changes in the protein which might occur also can be studied serologically. The effects of various amino acid analogues on growth and synthesis of flagella by Salmonella typhimurium were studied. Following addition of the analogues $p$-fluorophenylalanine ( $p$-FP), $\beta$-2-thienylalanine or ethionine to cultures of $S$. typhimurium growing logarithmically in a minimal medium, there was an immediate decrease in the growth rate (Fig. 1). Microscopic examination of the cultures at the end of the experiment showed that the bacteria were motile after incubation with $\beta$-2-thienylalanine or ethionine; long forms were present in the culture incubated with $\beta$-2-thienylalanine. Organisms incubated with $p$-FP became non-motile, and staining demonstrated the presence of abnormal flagella (Kerridge, 1959b).

In a previous paper (Kerridge, 1959 $a$ ) an investigation of flagellar regeneration by auxotrophic mutants of Salmonella typhimurium was reported. The effects of amino acid analogues on flagellar regeneration by certain of these strains was now studied and the results are shown in Table 5. S. typhimurium strain SW 577 was of 
interest as the flagella in this organism are aberrant, having a flagellar wavelength $(1 \cdot 0 \mu)$ half that usually found in $S$. typhimurium and the organisms are non-motile. Strain SW 577a is a motile variant isolated from strain SW 577, and the wavelength of the flagella is normal. After mechanical removal of flagella, bacteria of both strains regenerated flagella when incubated in a complete medium. Replacement of the phenylalanine of this medium by $p$-FP $(0.005 \mathrm{M})$ had no apparent effect on flagellar regeneration by strain SW 577 (non-motile), but with strain SW 577a (motile) the

Table 5. The effect of amino acid analogues on growth and on the regeneration of flagella by amino acid-requiring strains of Salmonella typhimurium

The regeneration of flagella was carried out in the complete regeneration medium, the amino acid required for growth being omitted when the amino acid analogue was added to the medium.

\begin{tabular}{|c|c|c|c|c|c|}
\hline $\begin{array}{l}\text { S. typhi- } \\
\text { murium } \\
\text { strain }\end{array}$ & Characteristic & $\begin{array}{l}\text { Analogue } \\
\text { (concn.) }\end{array}$ & Growth & $\begin{array}{l}\text { Motile } \\
\text { pacteria } \\
\text { er aerobic } \\
\text { cubation } \\
\text { or } 2 \mathrm{hr} \text {. } \\
\text { at } \mathbf{3 7 ^ { \circ }} \\
(\%)\end{array}$ & Flagella \\
\hline SW 577 & 'Curly' flagella & $p$-FP $(0.005 \mathrm{M})$ & $\begin{array}{l}+ \\
+\end{array}$ & $\begin{array}{l}\mathbf{5} \\
\mathbf{5}\end{array}$ & $\begin{array}{l}\text { Aberrant } \\
\text { Aberrant }\end{array}$ \\
\hline SW 577 a & $\begin{array}{l}\text { Normal variant isolated } \\
\text { from strain SW } 577\end{array}$ & $p$-FP (0.005 M) & $\begin{array}{l}+ \\
+\end{array}$ & $\begin{array}{l}50 \\
10\end{array}$ & $\begin{array}{l}\text { Normal } \\
\text { Aberrant }\end{array}$ \\
\hline SL 185 & Tyrosine-requiring & $\begin{array}{l}p \text {-FP }(0.005 \mathrm{M}) \\
\beta \text {-2-thienylalanine }(0.002 \mathrm{M})\end{array}$ & $\begin{array}{l}+ \\
- \\
-\end{array}$ & $\begin{array}{r}80 \\
1 \\
1\end{array}$ & $\begin{array}{l}\text { Normal } \\
\text { Absent } \\
\text { Absent }\end{array}$ \\
\hline SL282 & Tryptophan-requiring & $\begin{array}{l}\text {-tryptophan } \\
\text { 5-methyl tryptophan }(0.005 \mathrm{M})\end{array}$ & $\begin{array}{l}+ \\
-\end{array}$ & $\begin{array}{l}70 \\
60 \\
50\end{array}$ & $\begin{array}{l}\text { Normal } \\
\text { Normal } \\
\text { Normal }\end{array}$ \\
\hline SL448 & Phenylalanine-requiring & $\begin{array}{l}p \text {-FP }(0.005 \mathrm{M}) \\
\beta \text {-2-thienylalanine }(0.002 \mathrm{M})\end{array}$ & $\begin{array}{l}+ \\
\pm \\
\pm\end{array}$ & $\begin{array}{r}80 \\
5 \\
50\end{array}$ & $\begin{array}{l}\text { Normal } \\
\text { Aberrant } \\
\text { Normal }\end{array}$ \\
\hline
\end{tabular}

flagella synthesized in the presence of $p$-FP were morphologically similar to those of strain SW 577 and were non-functional. $p$-FP and $\beta$-2-thienylalanine were unable to replace tyrosine for flagellar regeneration by the tyrosine-requiring strain SL 185, but replaced phenylalanine for strain SL 448, abnormal flagella with a wavelength half that of the control being produced in the presence of $p$-FP. Replacement of the phenylalanine of the regeneration medium by $p$-FP $(0.004 \mathrm{M})$ had no effect on the net synthesis of nucleic acid or protein by $S$. typhimurium strain LT 2 during incubation for $90 \mathrm{~min}$., although there was a marked effect on the synthesis of functional flagella. Unlike $p$-FP, $\beta$-2-thienylalanine inhibited the net synthesis of nucleic acid and protein (Table 6), but synthesis of functional flagella occurred in the presence of $\beta$-2-thienylalanine. Addition of $p$-FP to motile cultures of $S$. typhimurium did not affect flagellar morphology or function; removal of the analogue from cultures with aberrant flagella and replacement by phenylalanine did not result in a reversion to the normal type of flagella. Chromatographic analysis (Boissonas, 1950) of the acid hydrolysates of the protein fraction and of flagella isolated from organisms incubated in the presence of $p$-FP showed the presence of the analogue in the protein. 
Table 6. The effect of amino acid analogues on the regeneration of flagella, and on nucleic acid and protein synthesis by Salmonella typhimurium strain $S W 1061$

\begin{tabular}{|c|c|c|c|c|c|c|c|}
\hline \multirow[b]{2}{*}{ Analogue } & \multirow[b]{2}{*}{$\begin{array}{c}\text { Conen. } \\
\text { (M) }\end{array}$} & \multicolumn{3}{|c|}{$\begin{array}{l}\text { Bacterial motility after } 2 \mathrm{hr} \text {. } \\
\text { aerobic incubation at } 37^{\circ} \text { in the } \\
\text { complete regeneration medium }\end{array}$} & \multicolumn{3}{|c|}{$\begin{array}{l}\text { Inhibition ( } \%) \text { of } \\
\text { synthesis after aerobic } \\
\text { incubation for } 2 \mathrm{hr} \text {. } \\
\text { in the complete } \\
\text { regeneration medium }\end{array}$} \\
\hline & & $\begin{array}{c}\text { Motile } \\
\text { bacteria } \\
(\%)\end{array}$ & $\begin{array}{c}\text { Flagellate } \\
\text { bacteria } \\
(\%)\end{array}$ & $\begin{array}{l}\text { Mean no. } \\
\text { flagella/ } \\
\text { flagellate } \\
\text { bacterium }\end{array}$ & $\begin{array}{c}\text { Total } \\
\text { nucleic } \\
\text { acid }\end{array}$ & DNA & Protein \\
\hline$p$-fluorophenylalanine & $\begin{array}{l}0 \\
0 \cdot 01\end{array}$ & $\begin{array}{l}90 \\
10\end{array}$ & $\begin{array}{l}96 \\
80\end{array}$ & $\begin{array}{l}\mathbf{3} \cdot \mathbf{0} \\
\mathbf{2} \cdot \mathbf{3}\end{array}$ & o & o & o \\
\hline$\beta$-2-thienylalanine & $\begin{array}{l}0 \\
0 \cdot 002 \\
0 \cdot 001\end{array}$ & $\begin{array}{l}90 \\
90 \\
85\end{array}$ & $\begin{array}{l}\dot{\cdot} \\
\dot{\cdot}\end{array}$ & $\begin{array}{l}\dot{\cdot} \\
\dot{\cdot}\end{array}$ & $\begin{array}{r}75 \\
50\end{array}$ & $\begin{array}{l}. \\
20 \\
40\end{array}$ & $\begin{array}{r}80 \\
40\end{array}$ \\
\hline
\end{tabular}

Purine and pyrimidine analogues. In Bacillus cereus, 8-azaguanine inhibits protein synthesis almost completely while being incorporated into the RNA. Chantrenne $\&$ Devreux (1958) compared its effect to that of chloramphenicol and suggested that the same mechanisms might be blocked in both cases. A differential effect of 8azaguanine on inducible and constitutive enzyme synthesis in Staphylococcus aureus was found by Creaser (1956). Flagellin behaves as a constitutive protein in Salmonella typhimurium (Kerridge, unpublished results) and it was of interest to study

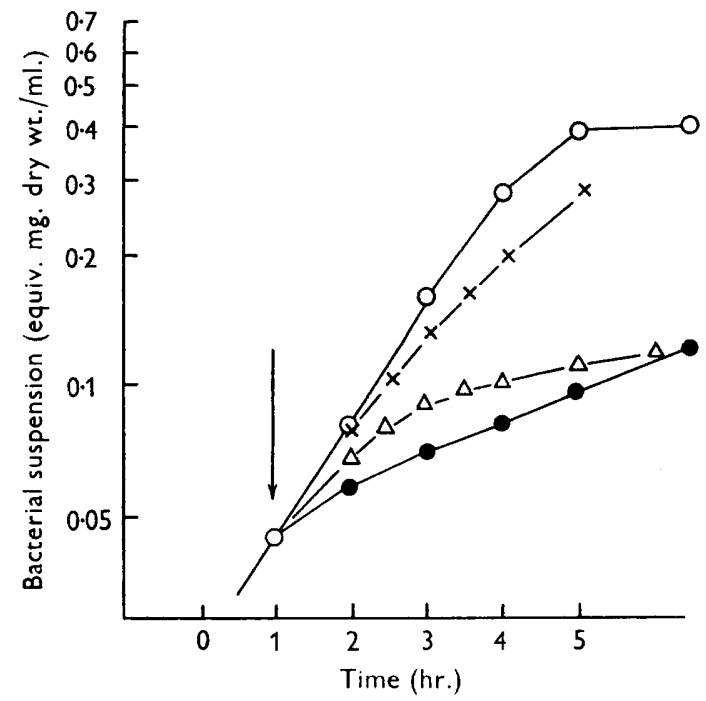

Fig. 1

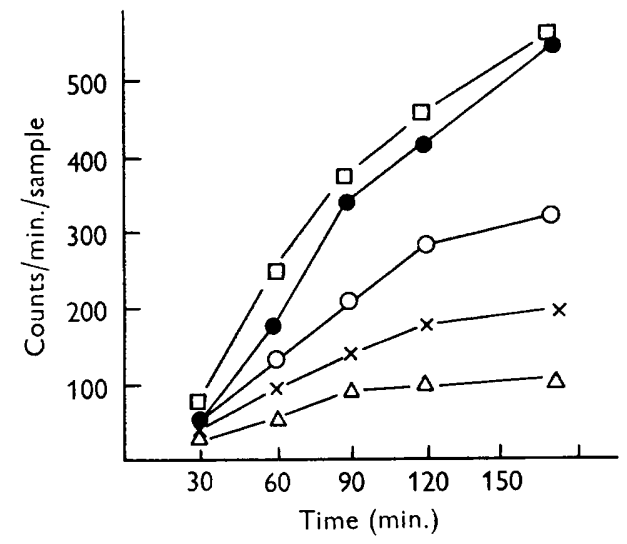

Fig. 2

Fig. 1. The effect of amino acid analogues on the growth of Salmonella typhimurium. $-\mathrm{O}-\mathrm{O}-=$ control $;-x-\mathrm{X}-=+$ ethionine $(0.005 \mathrm{M}) ;-\triangle-\triangle-=+p$-FP (0.005 M); $-0-=+\beta$-2-thienylalanine $(0.005 \mathrm{M})$.

Fig. 2. Inhibition of ${ }^{14} \mathrm{C}$-glycine incorporation into the nucleic acid and protein fractions of Salmonella typhimurium by 5-fluorouracil. - - - = protein, control; $-\mathrm{O}-\mathrm{O}-=$ nucleic acid, control ; $-\square-\square-=$ protein + fluorouracil $\left(7 \cdot 4 \times 10^{-4} \mathrm{M}\right) ;-\triangle-\triangle-=$ nucleic acid + fluorouracil $\left(7 \cdot 4 \times 10^{-4} \mathrm{M}\right) ;-x-x-=$ nucleic acid + fluorouracil $\left(7 \cdot 4 \times 10^{-5} \mathrm{M}\right)$. 
the effects of purine and pyrimidine analogues on the formation of flagella. Flagellar regeneration by $S$. typhimurium was not inhibited by 8 -azaguanine, even at $6.5 \times 10^{-4} \mathrm{M}$. There may have been some effect on the rate of flagellin synthesis, although the data suggest that this was not great. The flagella synthesized in the presence of 8-azaguanine were morphologically normal and were functional. Net protein and nucleic acid synthesis was $50 \%$ inhibited during incubation for $2 \mathrm{hr}$. with 8-azaguanine $\left(6.5 \times 10^{-4} \mathrm{M}\right)$, but DNA synthesis was not as sensitive as RNA synthesis (Table 7 ). 8-Azaguanine $\left(6.5 \times 10^{-5} \mathrm{M}\right)$ inhibited the synthesis of the inducible nitratase system in $S$. typhimurium by $95 \%$.

Table 7. The effect of purine and pyrimidine analogues on the regeneration of flagella, and on nucleic acid and protein synthesis by Salmonella typhimurium strain SW1061

\begin{tabular}{|c|c|c|c|c|c|c|c|}
\hline \multirow[b]{2}{*}{ Analogue } & \multirow[b]{2}{*}{$\begin{array}{c}\text { Concn. } \\
\left(\mathrm{M} \times 10^{-4}\right)\end{array}$} & \multicolumn{3}{|c|}{$\begin{array}{l}\text { Bacterial motility after } 2 \mathrm{hr} \text {. } \\
\text { aerobic ilicubation at } 37^{\circ} \text { in the } \\
\text { complete regeneration medium }\end{array}$} & \multicolumn{3}{|c|}{$\begin{array}{c}\text { Inhibition }(\%) \text { of } \\
\text { synthesis after } \\
\text { incubation for } 2 \mathrm{hr} . \\
\text { in the complete } \\
\text { regeneration medium }\end{array}$} \\
\hline & & $\begin{array}{c}\text { Motile } \\
\text { bacteria } \\
(\%)\end{array}$ & $\begin{array}{c}\text { Flagellate } \\
\text { bacteria } \\
(\%)\end{array}$ & $\begin{array}{c}\text { Mean no. } \\
\text { flagella/ } \\
\text { flagellate } \\
\text { bacterium }\end{array}$ & $\begin{array}{c}\text { Total } \\
\text { nucleic } \\
\text { acid }\end{array}$ & DNA & Protein \\
\hline 8-Azaguanine & $\begin{array}{l}0 \\
0 \cdot 65 \\
1 \cdot 9 \\
6 \cdot 5\end{array}$ & $\begin{array}{l}90 \\
90 \\
90 \\
90\end{array}$ & $\begin{array}{l}86 \\
94 \\
88 \\
95\end{array}$ & $\begin{array}{l}2 \cdot 5 \\
3 \cdot 2 \\
2 \cdot 5 \\
2 \cdot 8\end{array}$ & $\begin{array}{l}\dot{32} \\
42 \\
50\end{array}$ & $\begin{array}{l}\dot{16} \\
10 \\
16\end{array}$ & $\begin{array}{l}\dot{41} \\
51 \\
51\end{array}$ \\
\hline 2-Thiouracil & $\begin{array}{r}0 \\
30 \\
10 \\
30\end{array}$ & $\begin{array}{l}90 \\
90 \\
90\end{array}$ & $\begin{array}{c}84 \\
\dot{79}\end{array}$ & $\begin{array}{c}2 \cdot 6 \\
\dot{2} \\
2 \cdot 4\end{array}$ & $\begin{array}{l}\dot{46} \\
85 \\
86\end{array}$ & $\begin{array}{l}\dot{25} \\
69 \\
73\end{array}$ & $\begin{array}{l}\dot{37} \\
80 \\
88\end{array}$ \\
\hline 6-Azauracil & $\begin{array}{l}0 \\
0 \cdot 85 \\
2 \\
4 \cdot 3 \\
8 \cdot 5\end{array}$ & $\begin{array}{l}85 \\
75 \\
70 \\
65 \\
50\end{array}$ & $\begin{array}{l}85 \\
84 \\
70 \\
65 \\
66\end{array}$ & $\begin{array}{l}3 \cdot 7 \\
2 \cdot 8 \\
2 \cdot 6 \\
1 \cdot 9 \\
2 \cdot 1\end{array}$ & $\begin{array}{c}. \\
68 \\
95 \\
92 \\
.\end{array}$ & $\begin{array}{c}\dot{51} \\
68 \\
58 \\
.\end{array}$ & $\begin{array}{r}\dot{75} \\
87 \\
100 \\
.\end{array}$ \\
\hline 5-Fluorouracil & $\begin{array}{l}0 \\
0 \cdot 23 \\
2 \cdot 3 \\
7 \cdot 4\end{array}$ & $\begin{array}{l}80 \\
75 \\
80 \\
80\end{array}$ & $\begin{array}{l}80 \\
95 \\
86 \\
95\end{array}$ & $\begin{array}{l}3 \cdot 7 \\
6 \cdot 1 \\
7 \cdot 6 \\
7 \cdot 9\end{array}$ & $\begin{array}{l}\dot{.} \\
\dot{.}\end{array}$ & $\dot{.}$ & $\dot{.}$ \\
\hline FDUR* & $\begin{array}{l}0 \cdot 01 \\
0 \cdot 1 \\
1 \cdot 0\end{array}$ & $\begin{array}{l}80 \\
60 \\
60\end{array}$ & $\begin{array}{l}66 \\
62 \\
48\end{array}$ & $\begin{array}{l}3 \cdot 8 \\
4 \cdot 5 \\
5 \cdot 2\end{array}$ & $\begin{array}{c}. \\
\mathbf{5 0} \\
\mathbf{3 8}\end{array}$ & $\begin{array}{r}81 \\
90\end{array}$ & $\begin{array}{l}47 \\
36\end{array}$ \\
\hline
\end{tabular}

Hamers (1956) showed that 2-thiouracil was incorporated into the RNA fraction of Bacillus megaterium, replacing uracil, and that linear growth occurred in the presence of the analogue. The addition of 2-thiouracil to the regeneration medium had little or no effect on the ability of Salmonella typhimurium to regenerate functional flagella, whereas the synthesis of nucleic acid and protein was largely prevented (Table 7). DNA synthesis was inhibited less than either protein or total nucleic acid (RNA) synthesis.

Cohen et al. (1958) studied the effects of 5-fluorouracil and its derivatives on the growth of Escherichia coli and found that it was incorporated into the RNA of the bacteria. Fluorouracil is also converted to fluorodeoxyuridine (FDUR) which inter- 
feres with the functioning of thymidylate synthetase and results in the inhibition of DNA synthesis. FDUR is itself a very good inhibitor of growth of $\boldsymbol{E}$. coli, giving rise to 'unbalanced growth' and resulting in 'thymineless death'. 5-Fluorouracil had a differential effect on the rate of incorporation of ${ }^{14} \mathrm{C}$-labelled glycine into the nucleic acid and protein fractions of Salmonella typhimurium during incubation in the regeneration medium. At a concentration of $7 \cdot 4 \times 10^{-4} \mathrm{M}$ there was no effect on the rate of glycine incorporation into the protein fraction, but the incorporation of glycine into the nucleic acid fraction was initially slower than in the control and ceased after $90 \mathrm{~min}$. (Fig. 2). Regeneration of flagella was not inhibited and microscopic examination demonstrated that after incubation for $2 \mathrm{hr}$. in the regeneration medium there was a marked increase in the number of flagella/bacterium (Table 7). In the control culture there were approximately 4 flagella/bacterium, whereas in the culture incubated for $2 \mathrm{hr}$. in the presence of $7 \cdot 4 \times 10^{-4} \mathrm{M}-5$-fluorouracil, there were approximately 8 flagella/bacterium. This effect may have resulted from an inhibition of cell division, without any effect on the formation of flagella. FDUR had a differential effect on the net nucleic acid and protein synthesis, DNA synthesis being more sensitive to inhibition than either RNA or protein synthesis. FDUR had an effect similar to 5-fluorouracil on the regeneration of flagella; incubation in the presence of FDUR $\left(10^{-4} \mathrm{M}\right)$ resulted in an increase in the mean number of flagella/ bacterium. The effect was not as pronounced as in the case of 5-fluorouracil.

6-Azauracil was found by Otsuji \& Takagi (1959) to inhibit the synthesis of DNA by Escherichia coli $\mathrm{K} 12$ after a lag of $c .30 \mathrm{~min}$., while RNA and protein synthesis continue. These authors suggested that the inhibitory effects on growth were not necessarily due to an effect of the incorporation of the analogue into the nucleic acid, but might be due to an inhibition of cell-wall synthesis. A somewhat different result was obtained with Salmonella typhimurium. 6-Azauracil $\left(4 \times 10^{-5} \mathrm{M}\right)$ had no differential effect on net RNA, DNA and protein synthesis during incubation for $2 \mathrm{hr}$.: at higher concentrations RNA and protein synthesis were more strongly inhibited than DNA synthesis (Table 7). Regeneration of flagella occurred in the presence of $8.5 \times 10^{-4} \mathrm{M}$ 6-azauracil but at this concentration the mean number of flagella/ bacterium after incubation for $2 \mathrm{hr}$. was less than in the control culture. 5-Bromouracil, 5-nitrouracil, 4-methyl-2-thiouracil, isocytosine and 2:6-diaminopurine were also tested; they had no effect on growth or regeneration of flagella by $S$.typhimurium.

\section{Temperature effect; recovery of motility after growth at $44^{\circ}$}

Quadling \& Stocker (1956) found that it was possible to transfer a logarithmically growing culture of Salmonella typhimurium strain LT2 from $37^{\circ}$ to $44^{\circ}$ without affecting the growth rate. At $44^{\circ}$ there was a progressive decrease in the mean no. flagella/bacterium, and eventually the flagellated bacteria were diluted out. This effect was confirmed in the present work; a typical experimental result is shown in Fig. 3. There was no change in the growth rate of S.typhimurium strain SW 1061 on raising the temperature from $37^{\circ}$ to $44^{\circ}$. The mean no. flagella/bacterium remained constant for $1 \mathrm{hr}$. and then there was a progressive decrease in the no. flagella/ bacterium. The loss of motility was a phenotypic effect and on transfer to a favourable environment the bacteria recovered their motility.

Logarithmic growth continued after transferring a non-motile culture of Salmonella typhimurium from $44^{\circ}$ to $37^{\circ}$, but there was no immediate synthesis of 
flagella. Motile bacteria did not appear until about $45 \mathrm{~min}$. after the transfer and all organisms were not motile until after $c .90 \mathrm{~min}$. A comparison of the recovery of motility following growth at $44^{\circ}$ with regeneration of flagella after the mechanical removal of the flagella is shown in Fig. 4. The rates of growth and formation of flagella were similar in both cases, but there was a considerable difference in the length of the time lag before the appearance of flagella. It was considered possible that this lag might be due to the time taken by the bacteria to synthesize the system responsible for the formation and functioning of the flagellum. If the lag before the appearance of a flagellum at $37^{\circ}$, following incubation at $44^{\circ}$, represents the time required for the production of the synthesizing system, it should be possible to investigate the factors which affect the formation of a protein-synthesizing system by studying variations in this lag period.

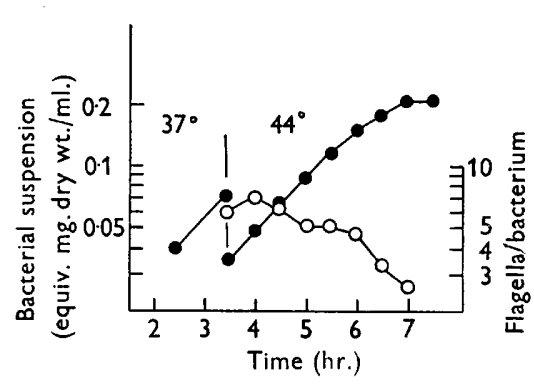

Fig. 3

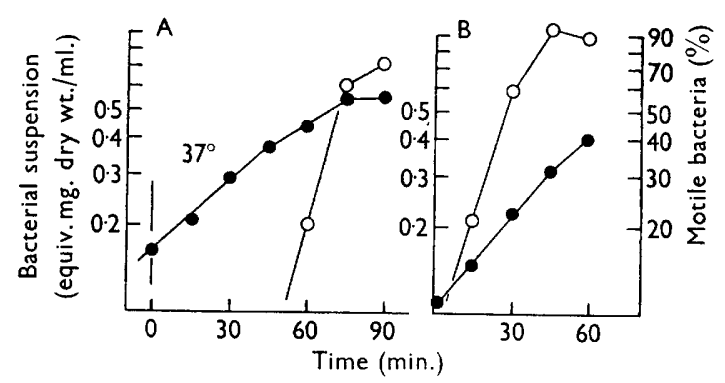

Fig. 4

Fig. 3. The effect of temperature on the growth of Salmonella typhimurium and on no. flagella/bacterium. - $-=$ suspension concentration; $-\mathrm{O}-\mathrm{O}-=$ no. flagella/ bacterium.

Fig. 4. A, Growth and recovery of motility at $37^{\circ}$ by a non-motile culture of Salmonella typhimurium after incubation at $44^{\circ} ; \mathrm{B}$, growth and flagellar regeneration at $37^{\circ}$ after mechanical removal of the flagella. - - - = suspension concentration; $-\mathrm{O}-\mathrm{O}-=\%$ motile bacteria.

\section{Inhibition of the recovery of motility after growth at $44^{\circ}$}

Effect of purine and pyrimidine analogues. Purine and pyrimidine analogues have no effect on regeneration of flagella in Salmonella typhimurium, but since several of these compounds have been found to affect enzyme synthesis in other bacteria, a study was made of their effects on the recovery of motility by $S$. typhimurium after growth at $44^{\circ}$. An overnight culture of $S$. typhimurium in the Casamino acids salts medium was diluted tenfold with similar medium, and incubation continued at $\mathbf{4 4}^{\circ}$. After $4 \mathrm{hr}$. the culture was diluted with an equal volume of medium and incubated at $37^{\circ}$. Addition of 2-thiouracil $(0.001 \mathrm{M})$ to the culture at the time of transfer to $37^{\circ}$ resulted in a progressive inhibition of growth. After incubation for $2.5 \mathrm{hr}$. at $37^{\circ}$ the bacteria remained non-motile and flagella could not be demonstrated by staining. A similar result was obtained using 8-azaguanine. The control culture continued to grow logarithmically after transferring to $37^{\circ}$ and after incubation for $2 \mathrm{hr}$. at least $80 \%$ of the bacteria were motile (Fig. 5). As neither 2-thiouracil nor 8-azaguanine had been shown to have any marked inhibitory effects on regeneration of flagella at $37^{\circ}$ after mechanical detachment of the flagella (Table 7 ), it seemed probable that the inhibition of recovery of motility was not due to an effect on flagellin synthesis 
itself, but rather to an effect on the formation of the synthesizing system. This hypothesis was studied by investigating the effects of delaying the addition of the analogue.

A non-motile culture of Salmonella typhimurium growing logarithmically at $44^{\circ}$ was diluted with an equal volume of growth medium and incubated at $37^{\circ}$. Immediately after the dilution and then at $30 \mathrm{~min}$. intervals, $20 \mathrm{ml}$. samples were taken and 8 -azaguanine added (to final concentration $0.001 \mathrm{M}$ ) to them. The cultures were incubated at $37^{\circ}$ and sampled at intervals for the determination of the quantity of

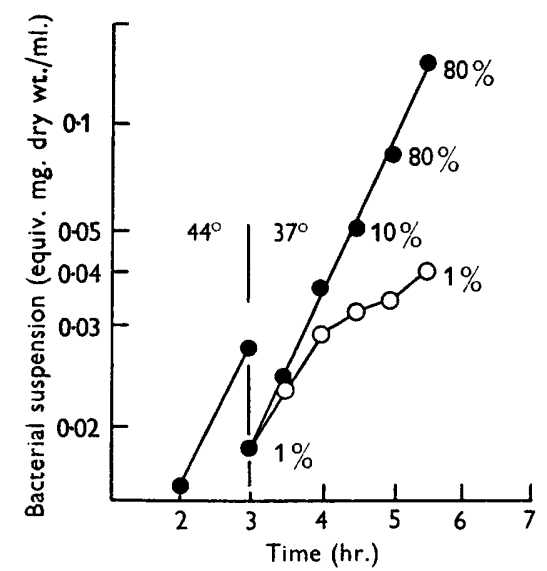

Fig. 5

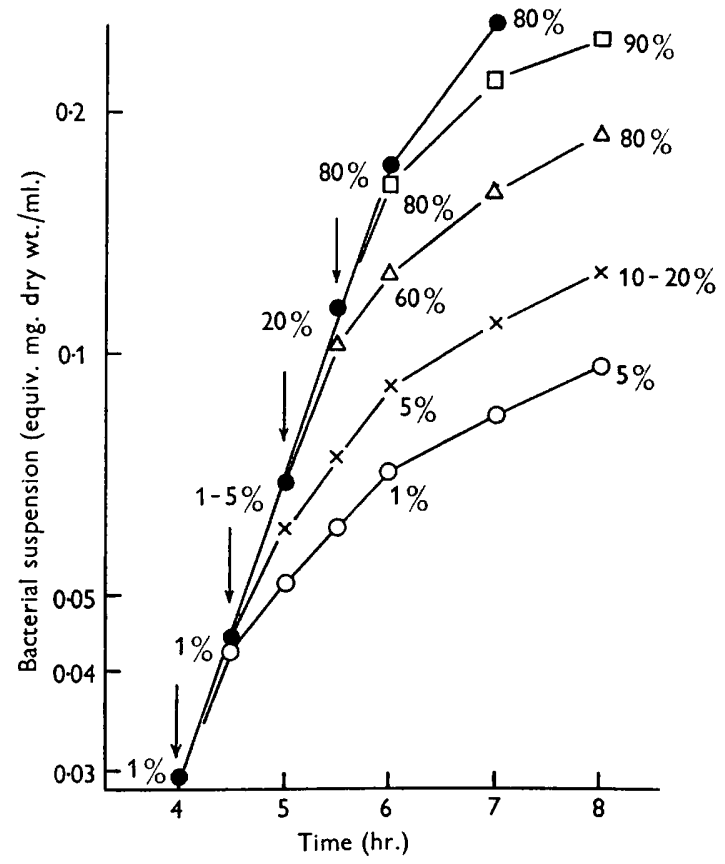

Fig. 6

Fig. 5. The effect of 2-thiouracil on the growth and recovery of motility by a nonmotile culture of Salmonella typhimurium. - - - = control; $-\mathrm{O}-\mathrm{O}-=+2$-thiouracil $(0.001 \mathrm{M})$. The numbers denote $\%$ motile bacteria.

Fig. 6. The effect of the time of addition of 8-azaguanine on the growth and recovery of motility by a non-motile culture of Salmonella typhimurium. - $-1-=$ control; $-\mathrm{O}-\mathrm{O}-=8$-azaguanine $(0.001 \mathrm{M})$ added immediately after transfer from $44^{\circ} \rightarrow 37^{\circ}$; $x-x-=8$-azaguanine $(0 \cdot 001 \mathrm{M})$ added $30 \mathrm{~min}$. after transfer $;-\triangle-\triangle-=8$-azaguanine $(0.001 \mathrm{M})$ added $60 \mathrm{~min}$. after transfer; $-\square-\square-=8$-azaguanine (0.001 $\mathrm{M})$ added $90 \mathrm{~min}$. after transfer. Numbers denote \% motile bacteria.

bacteria and their motility (Fig. 6). After the addition of 8-azaguanine the growth rate was decreased and the rate of growth was no longer logarithmic. The recovery of motility was completely inhibited by the analogue when added immediately after transfer to $37^{\circ}$; less than $5 \%$ of the bacteria were motile after $4 \mathrm{hr}$. at $37^{\circ}$ as compared to $90 \%$ in the control culture. Delay in the addition of 8 -azaguanine for $1 \mathrm{hr}$. had little effect on the subsequent formation of flagella, although the growth rate was decreased. At the time of addition of the inhibitor, less than $5 \%$ of the bacteria were flagellate, but $1 \mathrm{hr}$. later $60 \%$ of the bacteria were motile. Examination of 
stained preparations showed a good correlation between the $\%$ flagellate bacteria and the $\%$ motile bacteria. If the flagella arise from synthesizing systems present in the bacteria then the effects of the analogues might be explained by assuming that the synthesis but not the functioning of these systems is sensitive to inhibition by 8 -azaguanine and 2 -thiouracil.

During logarithmic growth the mean no. flagella/bacterium and, by implication, the number of synthesizing systems remains approximately constant; there was a decrease during the stationary phase, probably due to cell division in the absence of growth. Addition of either 2-thiouracil (0.001 M) or 8-azaguanine $(0.001 \mathrm{M})$ to a culture of Salmonella typhimurium growing logarithmically at $37^{\circ}$ resulted in an immediate decrease in the growth rate (Fig. 7). There was little change in the mean

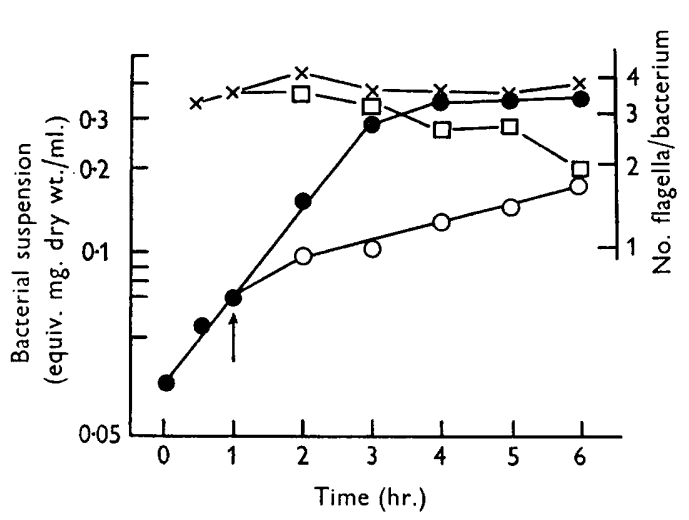

Fig. 7

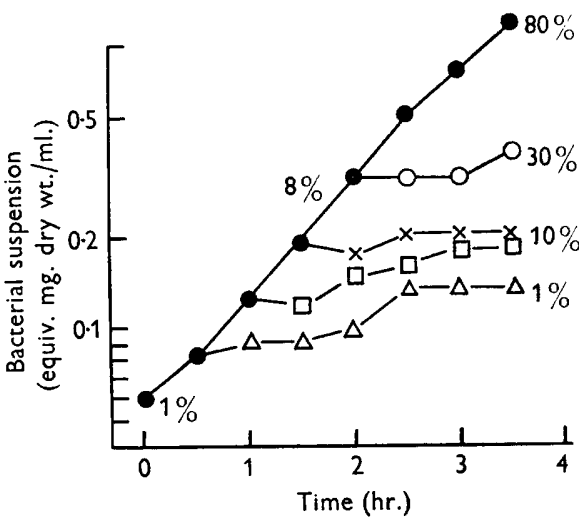

Fig. 8

Fig. 7. The effect of 8-azaguanine on growth of Salmonella typhimurium in a Casaminoacids + salts medium at $37^{\circ}$ and on no. flagella/bacterium. -0-0- = growth, control culture ; $-\mathrm{O}-\mathrm{O}-=$ growth +8 -azaguanine $(0.001 \mathrm{M}) ; x-x-=$ no. flagella/bacterium, control culture; $-\square-\square-=$ no. flagella/bacterium, in presence of 8-azaguanine (0.001 $\mathrm{M})$.

Fig. 8. The effect of 6 -azauracil $\left(4 \cdot 3 \times 10^{-4} \mathrm{M}\right)$ on growth and recovery of motility at $37^{\circ}$ by a non-motile culture of Salmonella typhimurium. $--0-=$ control ; $\triangle-\triangle-=$ 6 -azauracil added 30 min. after transferring the culture from $44^{\circ} \rightarrow 37^{\circ} ; \square-\square-=6$ azauracil added 60 min. after transfer; $\times-\times-=6$-azauracil added 90 min. after transfer; $-\mathrm{O}-\mathrm{O}-=6$-azauracil added $120 \mathrm{~min}$. after transfer. The numbers denote $\%$ motile bacteria.

no. flagella/bacterium for $2 \mathrm{hr}$. after the addition of the inhibitor. Then the no. flagella/bacterium decreased and after $5 \mathrm{hr}$. was approximately half that of the control culture. The bacteria were still motile at the end of incubation, 2 -thiouracil and 8-azaguanine apparently having had no effect on the functioning of preformed synthesizing systems. It would appear from these data that 2-thiouracil and 8azaguanine inhibit the synthesis of functional synthesizing systems but do not completely inhibit growth and cell division, so leading to the decrease in the no. flagella/bacterium. Incubation of a non-motile culture of $S$. typhimurium for $\mathbf{2} \mathbf{~ h r}$. at $44^{\circ}$ with 8 -azaguanine $(0.001 \mathrm{M})$ had no effect on the growth rate or the recovery of motility at $37^{\circ}$ after the removal of the inhibitor.

Since none of the purine and pyrimidine analogues tested completely inhibited the regeneration of flagella by mechanically deflagellated Salmonella typhimurium it was possible to study the effects of these analogues on the formation of the synthesizing 
system. Inhibition by 6-azauracil did not produce such clear-cut results as did 2-thiouracil or 8-azaguanine (Fig. 8). Bacterial lysis resulted from the addition of 5 -fluorouracil $\left(3 \cdot 8 \times 10^{-4} \mathrm{M}\right)$ or FDUR $\left(10^{-4} \mathrm{M}\right)$ to a growing culture of $S$. typhimurium. 5-Fluorouracil $\left(3.8 \times 10^{-4} \mathrm{M}\right)$ inhibited the formation of the synthesizing system by S. typhimurium during incubation at $37^{\circ}$ after growth at $44^{\circ}$, a result similar to that obtained with 8-azaguanine. Addition of 5-fluorouracil after incubation for $90 \mathrm{~min}$. at $37^{\circ}$ caused a decrease in the turbidity of the suspension due to bacterial lysis. Microscopic examination, however, showed that although only $5 \%$ of the bacteria were motile at the time of addition, after incubation for $\mathbf{9 0} \mathrm{min}$. this had increased to $60 \%$ (Fig. 9). FDUR $\left(10^{-4} \mathrm{M}\right)$ completely inhibited growth of $S$. typhimurium at $37^{\circ}$ but at this concentration did not completely inhibit the recovery of motility, and after incubation for $3 \mathrm{hr}$. c. $15 \%$ of the bacteria were flagellate (Fig. 10).

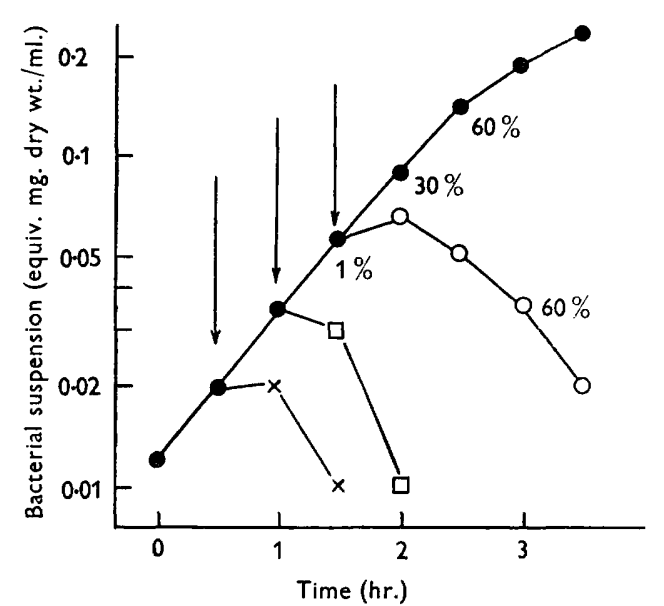

Fig. 9

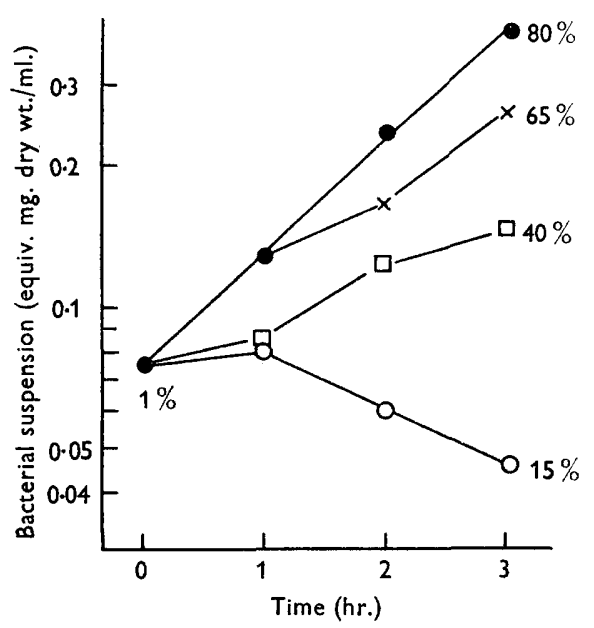

Fig. 10

Fig. 9. The effect of 5 -fluorouracil $\left(3.8 \times 10^{-4} \mathrm{M}\right)$ on the growth and recovery of motility at $37^{\circ}$ by a non-motile culture of Salmonella typhimurium. $--1-=$ control; $-x-\times-=$ 5-fluorouracil added $30 \mathrm{~min}$. after transfer from $44^{\circ} \rightarrow 37^{\circ} ;-\square-\square-=5$-fluorouracil added $60 \mathrm{~min}$. after transfer; $-\mathrm{O}-\mathrm{O}-=5$-fluorouracil added $90 \mathrm{~min}$. after transfer. The numbers denote \% motile bacteria.

Fig. 10. The effect of fluorodeoxyuridine (FDUR) on growth and recovery of motility by a non-motile culture of Salmonella typhimurium. $-0-=$ control; $-\times-\times-=$ $+10^{-6}$ M FDUR; $-\square-\square-=+10^{-5}$ M FDUR; $-\mathrm{O}-\mathrm{O}-=+10^{-4}$ M FDUR. The numbers denote $\%$ motile bacteria.

Amino acid analogues. The growth of Salmonella typhimurium in a defined medium was affected by a number of amino acid analogues; but apart from $\boldsymbol{p}$-FP none of the analogues tested inhibited the regeneration of functional flagella after mechanical removal. Addition of $p$-FP or $\beta$-2-thienylalanine $(0.005 \mathrm{M})$ to cultures of $S$.typhimurium after growth at $44^{\circ}$ prevented recovery of motility on incubation at $37^{\circ}$. The data for $p$-FP are shown in Fig. $11 ; \beta$-2-thienylalanine gave essentially similar results.

Nitrogen mustard. Under suitable conditions nitrogen mustard will specifically inhibit DNA synthesis in micro-organisms, without completely inhibiting synthesis of RNA and protein. Pretreatment of deflagellated suspensions of Salmonella 
typhimurium with nitrogen mustard resulted in inhibition of regeneration of flagella during subsequent incubation in a complete medium (Table 3). Recovery of motility by $S$. typhimurium after growth at $44^{\circ}$ was also inhibited by nitrogen mustard. Samples $(10 \mathrm{ml}$.) were taken from a culture of $S$. typhimurium growing logarithmically at $44^{\circ}$, and incubated with different concentrations of nitrogen mustard for $10 \mathrm{~min}$. at room temperature. The bacteria were harvested by centrifugation and resuspended in $20 \mathrm{ml}$. Casamino acid + salts + glucose medium and incubated at $37^{\circ}$.

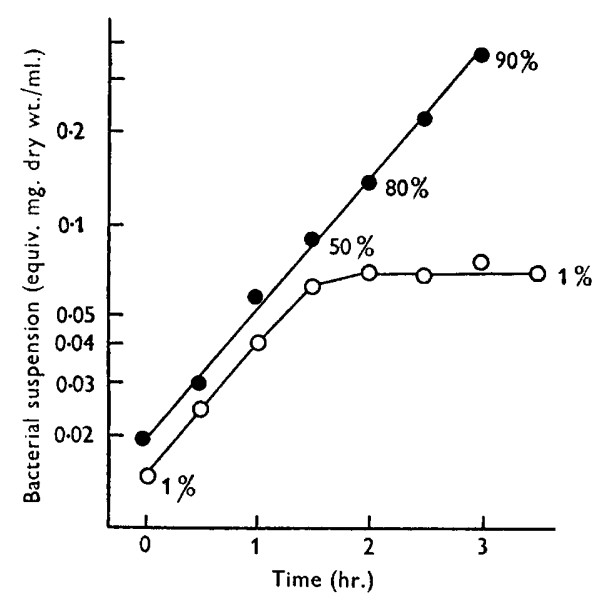

Fig. 11

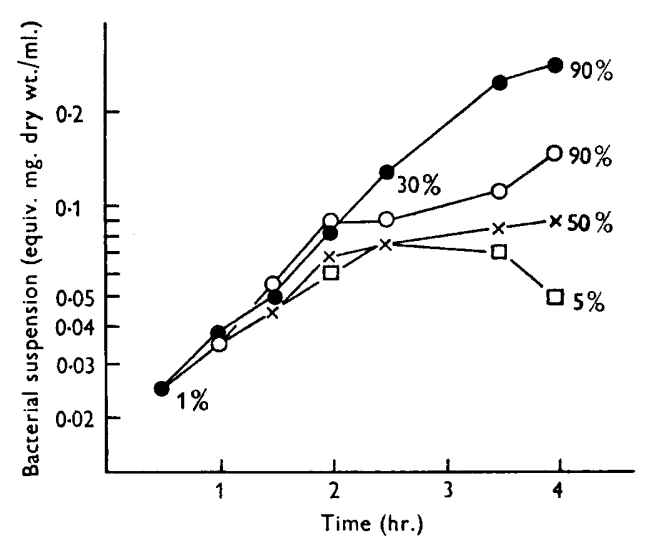

Fig. 12

Fig. 11. The effect of $p$-fluorophenylalanine on growth and recovery of motility at $37^{\circ}$ by a non-motile culture of Salmonella typhimurium. $-0-0-=$ control; $-\mathrm{O}_{-}-\mathrm{O}_{-}^{-}=$ $+p$-FP (0.005 $\mathrm{M})$. The numbers denote $\%$ motile bacteria.

Fig. 12. The effect of pretreatment with nitrogen mustard on growth and recovery of motility by a non-motile culture of Salmonella typhimurium. - - - $=$ control; $-\mathrm{O}-\mathrm{O}-$ $=+100 \mu \mathrm{g}$. nitrogen mustard $/ \mathrm{ml}$; $-x-x-=+250 \mu \mathrm{g}$. nitrogen mustard $/ \mathrm{ml}$; $-\square-\square-$ $=+500 \mu \mathrm{g}$. nitrogen mustard $/ \mathrm{ml}$. The numbers denote $\%$ motile bacteria.

Bacterial growth and motility were followed during the incubation at $37^{\circ}$ (Fig. 12). Treatment with $100 \mu \mathrm{g}$. nitrogen mustard/ml. had little effect on the increase in optical density of the culture during the first $90 \mathrm{~min}$. of incubation at $37^{\circ}$; after this there was some decrease in the rate of increase. Recovery of motility was similar to that of the control culture. With higher concentrations of nitrogen mustard there was some diminution in the initial increase in optical density at $37^{\circ}$ and a progressive loss of ability to form flagella. Long forms were produced during incubation at $37^{\circ}$; some of these were motile and microscopic examination after flagellar staining showed that these forms possessed large numbers of flagella, suggesting that although cell division was inhibited, the synthesis of the synthesizing system and flagella occurred.

\section{DISCUSSION}

Cytological studies on motile bacteria have shown that in many cases the flagella originate from basal granules within the bacterial cell. These granules (blepharoplasts) have been clearly demonstrated in autolysed preparations from Vibrio metchnikovi, Proteus vulgaris, Chromobacterium violaceum (van Iterson, 1953), V. cholerae, Rhodospirillum rubrum (Grace, 1954), and V. comma (Tawara, 1957). 
With the exception of $\boldsymbol{R}$. rubrum, where several flagella are attached to one basal granule, each flagellum arises from a single basal granule. Houwink (1953) demonstrated hook-like bends at the base of each flagellum in a Spirillum sp. and van Iterson (1953) found similar 'hooks' at the ends of flagella torn out from Proteus vulgaris. Basal granules have not yet been demonstrated in Salmonella typhimurium, but it is a reasonable assumption that the flagella of this organism originate from subcellular structures ('basal granules') responsible for flagella synthesis and function.

The phenotypic expression of the ability to produce flagella is affected by the environment. For a number of bacterial species including Pasteurella pseudotuberculosis (Preston \& Maitland, 1952), Salmonella typhimurium (Quadling \& Stocker, 1956) and Bacillus megaterium (Vennes \& Gerhardt, 1959) an increase in growth temperature results in the production of non-motile organisms although growth is unaffected. The transfer of a logarithmically growing culture of $S$. typhimurium from $37^{\circ}$ to $44^{\circ}$ results in a decrease in mean no. flagella/bacterium without affecting the growth rate, and on continued incubation at $44^{\circ}$ the motile bacteria are diluted out. As regeneration of flagella can occur at $44^{\circ}$, it seems unlikely that the loss of motility was due to an inhibition of flagellar synthesis itself. Subsequent transfer of a non-motile culture from $44^{\circ}$ to $37^{\circ}$ results in the recovery of motility after a lag period equal to the mean generation time of the organisms, suggesting that a temperature-sensitive reaction is involved in the formation of the flagellum-synthesizing system.

None of the amino acid, purine or pyrimidine analogues tested, with the exception of $p$-FP, completely inhibited the regeneration of functional flagella by Salmonella typhimurium. Flagella synthesized in the presence of $p$-FP were non-functional and morphologically abnormal; the flagellar wavelength was approximately half that of normal flagella, $1 \cdot 04 \mu \pm 0 \cdot 14 \mu$ (s.D.) as compared with $2 \cdot 08 \mu \pm 0 \cdot 1 \mu$. The occurrence of two distinct flagellar wavelengths has been reported for a number of bacterial species; Pijper (1955) proposed the term 'biplicity' for this phenomenon. Unlike the changes in flagellar wavelength induced by variation in the $\mathrm{pH}$ value of the medium, the change in wavelength due to synthesis in the presence of $p$-FP was not reversible.

Data from experiments of the effects of inhibitors on the recovery of motility support the hypothesis that the 'basal granules' are absent from Salmonella typhimurium grown at $44^{\circ}$ and are resynthesized at $37^{\circ}$ during the lag before the appearance of flagella. Purine and pyrimidine analogues did not inhibit regeneration of flagella at $37^{\circ}$ but prevented recovery of motility by $S$. typhimurium at $37^{\circ}$ after growth at $44^{\circ}$. The apparent discrepancy between these data was resolved by the results of studying the effect of the time of addition of the analogue on the subsequent formation of flagella. Addition of 8 -azaguanine $(0.001 \mathrm{M})$, immediately after transferring a non-motile culture of $S$. typhimurium from $44^{\circ}$ to $37^{\circ}$, resulted in the complete inhibition of formation of flagella; but when the addition of the analogue was delayed for $1 \mathrm{hr}$., formation of flagella was not affected, although at the time of addition only $5 \%$ of the bacteria were flagellate. The formation of 'basal granules' in cultures growing logarithmically at $37^{\circ}$ was also inhibited by 8 -azaguanine and 2-thiouracil. Growth of the bacteria, although decreased, was not completely prevented, and there was a progressive decrease in the no. flagella/bacterium. 
This effect is somewhat like that of temperature on formation of flagella, although in the latter case growth was not affected.

Since the addition of 8-azaguanine to logarithmically growing cultures of Salmonella typhimurium at $44^{\circ}$ did not prevent the subsequent formation of flagella at $37^{\circ}$ after the removal of the analogue, this suggests that macromolecular precursors of the 'basal granules' are not present at $44^{\circ}$ but are synthesized de novo on transfer to $37^{\circ}$.

It is tempting to speculate on the nature of the 'basal granule' in Salmonella typhimurium. As flagella consist only of protein it is a logical assumption that the formation of the 'basal granules' will involve synthesis of ribonucleoprotein. The inhibition of the synthesis of the 'basal granules' by purine, pyrimidine or amino acid analogues would then be explicable, by assuming that the incorporation of these compounds results in the formation of an inactive ribonucleoprotein complex. The fact that these compounds have no effect on regeneration of flagella at $37^{\circ}$ suggests that although synthesis of an active ribonucleoprotein complex may be essential for the formation of a functional 'basal granule', the further synthesis of a functional flagellum does not require concomitant synthesis of a biologically active RNA.

There is a marked parallelism between the data on the formation of bacterial flagella by Salmonella typhimurium and those obtained by Jeener, Hamers-Casterman \& Mairesse (1959) on bacteriophage synthesis by a lysogenic strain of Bacillus megaterium. The synthesis of the phage was more sensitive to inhibition by 8 azaguanine and 2-thiouracil than was the formation of general cell protein. The data are consistent with the hypothesis that phage synthesis requires the prior formation of a particulate RNA fraction. Addition of 2-thiouracil or 8-azaguanine might be expected to result in much greater structural changes in the RNA required for phage synthesis, than in the RNA which determines the specificity of bacterial proteins, so accounting for the selective effect of these analogues.

\section{REFERENCES}

Ambler, R. P. \& Rees, M. W. (1959). N-Methyl-lysine in bacterial flagellar protein. Nature, Lond. 184, 56.

Anand, N. \& Davis, B. D. (1960). Damage by streptomycin to the cell membrane of Escherichia coli. Nature, Lond. 185, 22.

BAKER, R. S., Johnson, J. E. \& Fox, S. W. (1958). Incorporation of $p$-fluorophenylalanine into proteins of Lactobacillus arabinosus. Biochim. biophys. acta, 28, 318.

Borssonas, R. A. (1950). Separation rapide des acides amines par chromatographie ascendante bidimensionelle sur papier. Helv. chim. acta, 33, 19.

Burton, K. (1956). A study of the conditions and mechanisms of the diphenylamine estimation of desoxyribonucleic acid. Biochem. J. 62, 315.

Chantrenne, H. \& Devreux, S. (1958). Deterioration progressive des centres de synthese des protéines par un analogue de la guanine. Arch. int. Phys. Biochem. 67, 505.

Cohen, S. S., Flaks, J. G., Barner, H. D., Loeb, M. R. \& Lichtenstein, J. |(1958). The mode of action of 5-fluoro-uracil and its derivatives. Proc. nat. Acad. Sci., Wash. 44, 1004.

Creaser, E. H. (1956). The assimilation of amino acids by bacteria. 22. The effect of 8-azaguanine upon enzyme formation in Staphylococcus aureus. Biochem. J. 64, 539.

Demerec, M., Hartman, Z., Hartman, P. E., Yura, T., Demerec, Z. E., Gots, J. C., Ozeki, H. \& Glover, S. W. (1956). Genetic studies with bacteria. Publ. Carneg. Instn, no. 612 . 
Frtzgerald, R. J., Bernheim, F. \& Fitzgerald, D. B. (1948). The inhibition by streptomycin of adaptive enzyme formation in Mycobacteria. J. biol. Chem. 175, 195.

Gale, E. F. \& Folkes, J. P. (1953). The assimilation of amino acids by bacteria. 15. Actions of antibiotics on nucleic acid and protein synthesis in Staphylococcus aureus. Biochem. J. 53, 493.

Gaxe, E. F. \& Paine, T. F. (1951). The assimilation of amino acids by bacteria. 12. The action of inhibitors and antibiotics on the accumulation of free glutamic acid and the formation of combined glutamate in Staphylococcus aureus. Biochem. J. 48, 298.

Grace, J. B. (1954). Some observations on the flagella and blepharoplasts of Spirillum and Vibrio spp. J. gen. Microbiol. 10, 325.

Hahn, F. E. \& Wisseman, C. L. (1951). Inhibition of adaptive enzyme formation by antimicrobial agents. Proc. Soc. exp. Biol., N.Y. 76, 533.

HAMERS, R. (1956). Incorporation of ${ }^{35} \mathrm{~S}$ thiouracil in Bacillus megaterium. Biochim. biophys. acta, $21,170$.

HARold, F. M. \& Ziporin, Z. Z. (1958). Effect of nitrogen and sulphur mustard on nucleic acid synthesis in Escherichia coli. Biochim. biophys. acta, 28, 482.

Houwink, A. L. (1953). A macromolecular monolayer in the cell wall of Spirillum spp. Biochim. biophys. acta, 10, 350.

ITERSON, W. vaN (1953). Some remarks on the present state of our knowledge of bacterial flagellation. Symp. 6th Congr. int. Microbiol. Bacterial cytology, p. 24.

Jekner, R., Hamers-Casterman, C. \& Mairesse, N. (1959). On the inhibition of phage production by 2-thiouracil and 8-azaguanine in an induced lysogenic Bacillus megaterium. Biochim. biophys. acta, 35, 166.

Kauffmann, F. (1954). Enterobacteriaceae. Copenhagen: Ejnar Munksgaard.

Kelner, A. (1953). Growth, respiration and nucleic acid synthesis in UV irradiated and photoreactivated Escherichia coli. J. Bact. 65, 252.

KerRIDGe, D. (1959a). Synthesis of flagella by amino acid-requiring mutants of Salmonella typhimurium. J. gen. Microbiol. 21, 168.

KernidGe, D. (1959b). The effect of amino acid analogues on the synthesis of bacterial flagella. Biochim. biophys. acta, 31, 579.

Lowry, O. H., Rosebrough, N. J., Farr, A. L. \& Randall, R. J. (1951). Protein measurement with the Folin-phenol reagent. J. biol. Chem. 193, 265.

MatThews, R. E. F. (1953). Incorporation of 8-azaguanine into nucleic acid of tobacco mosaic virus. Nature, Lond. 171, 1065.

Mires, A. A. \& Misra, S. S. (1938). The estimation of the bactericidal power of blood. J. Hyg., Camb. 38, 732.

Munier, R. \& Conen, G. N. (1956). Incorporation d'analogues structuraux d'amino acides dans les protéines bactériennes. Biochim. biophys. acta, 21, 593.

Munier, R. \& Comen, G. N. (1959). Incorporation d'analogues structuraux d'amino acides dans les protéines bactériennes au cours de leurs syntheses in vivo. Biochim. biophys. acta, 31, 378.

OtsuJI, N. \& TAKagi, Y. (1959). Effect of 6-azauracil on cells and subcellular preparations of Escherichia coli. Biochem. J., Japan, 46, 791.

Park, J. T. \& Strominger, J. L. (1957). Mode of action of penicillin. Science, 125, 99.

Pisper, A. (1955). Shape of bacterial flagella. Nature, Lond. 175, 214.

Pollock, M. R. (1946). Adaptation of nitratase in washed suspensions of bacteria. Brit. J. exp. Path. 27, 419.

Preston, N. W. \& Maitrand, H. B. (1952). The influence of temperature on the motility of Pasteurella pseudotuberculosis. J. gen. Microbiol. 7, 117.

Quading, C. \& Stocker, B. A. D. (1956). An experimentally induced transition from flagellated to non-flagellated state in Salmonella: the fate of bacterial flagella at cell division. J. gen. Microbiol. 15, i.

Rrcemond, M. H. (1959). Effect of inhibitors on lytic enzyme synthesis in Bacillus subtilis R. Biochim. biophys. acta, 34, 325.

Robertis, E. DE \& Peluffo, C. A. (1951). Chemical stimulation and inhibition of bacterial motility studied with a new method. Proc. Soc. exp. Biol., N.Y. 78, 584. 
Stocker, B. A. D. (1957). Methods of removing flagella from live bacteria; effects on motility. J. Path. Bact. 73, 314.

Stocker, B. A. D. \& Campreli, J. C. (1959). The effect of non-lethal deflagellation on bacterial motility and observations on flagellar regeneration. J. gen. Microbiol. 20,670.

Tawara, J. (1957). Electron-microscopic study on the flagella of Vibrio comma. J. Bact. 73, 89.

Vennes, J. W. \& Gerhardt, P. (1959). Antigenic analysis of cell structures isolated from Bacillus megaterium. J. Bact. 77, 581.

Zinder, N. D. \& Lederberg, J. (1952). Genetic exchange in Salmonella. J. Bact. 64, 679. 